\title{
Bad Faith Lawsuit in America and Improvement of Chinese Insurance Law
}

\author{
Qinghua Huang \\ School of Law, the University of Sheffield \\ DG 10 Bartolome House, Winter Street, Sheffield, S3 7ND, UK \\ Tel: 44-75-1744-6298Ｅ-mail: huanqinghua188@163.com
}

\begin{abstract}
This article discusses the main differences in dealing with insurers' bad faith under American and Chinese insurance law, and recommends Chinese Government introducing the American bad faith lawsuit to China. For this purpose, the nature, essence, and the general and specific requirements of bad faith lawsuit in America is firstly presented. Then, the article states how insurers' bad faith in China is handled in accordance with the Chinese insurance law: remedy for breach of the contractual obligation, and public law sanction. Further, new practices of legislation, justice, administration, and self-discipline of the insurance industry for preventing and handling insurers' bad faith in China, are also represented. Finally, through the analysis of jurisprudence and comparative law, the article analyzes the necessity of introducing American bad faith lawsuit into China, and the requirements of the legal reform for the introduction.
\end{abstract}

Keywords: Bed faith lawsuit, Fair dealing, Insurance law, Comparative law, American law, Chinese law

\section{Introduction}

All insurance policies contain an implied obligation applicable to insurance company of "good faith and fair dealing" towards its insured. This is a basic rule in both Chinese and American insurance law. The rule requires that an insurance company can not simply look for reasons not to pay when a claim is presented. Instead, an insurance company must make a thorough investigation of the claim, must consider all reasons and circumstances that might sustain the claim, and must give as much consideration to the financial interest of the insured as the insurer gives to its own financial interest.

It is generally recognized that an insurer's conduct may constitute bad faith if the insurer violates the foregoing stated duty in dealing with an insured's claim. If the bad faith conduct took place in USA, the insured in most states, pursuant to respective state's insurance law, may bring bad faith litigation against the insurance company for damages. The legal basis supporting bad faith lawsuits is that an insurance company would break its implied obligation of good faith and fair dealing, if the insurer refuses or denies paying a claim that should be paid, or offers to settle a claim for less than it knows the claim is worth, without adequate investigation or without reasonable grounds.

The fundamental principle of bad faith lawsuit under the American insurance law provides us a reference, by which we could, in solving the problem of Chinese insurers' bad faith, to compare and contrast the provisions of the Insurance Law of People's Republic of China (hereafter referred as the Chinese Insurance Law) and its practice. Thus, this article will, firstly, introduce bad faith lawsuit under the American insurance law in detail; then, represent the problem of insurers' bad faith in China, and describe the endeavors that Chinese government, consumers' institute and insurance industry have made for resolving the problem; finally, suggest to introduce the legal mechanism of bad faith lawsuit into China, and provide corresponding reasons, from the perspective of reforming Chinese legal system and improving the Chinese Insurance Law.

\section{Bad Faith Lawsuit under American Insurance Law}

\subsection{Nature and Essence of Bad Faith Litigation}

Bad faith litigation is designed, in the majority of state courts, to protect the interests of insured in their dealings with insurance companies (Dobbyn 2001). In the U.S., bad faith involves something more than negligence, and implies conscious wrongdoing for a dishonest purpose. If an insurance company is found to have acted in bad faith in its handling of a claim, the insured is entitled to all damages resulting from that action, including certain types of damages that would not be available just for breach of contract. In cases of extreme or outrageous misconduct by an insurance company, the insured also may be entitled to receive punitive damages. This is called bad faith litigation. Courts often have held bad faith on the part of insurers, even though when their dispute with plaintiffs over the existence or amount of coverage was reasonable, and courts have awarded damages to claimants many times over the disputed amount in some cases (Harrington and Niehaus 2003). This is because many state courts have accepted claims for punitive damages against insurers based on bad faith, although not all jurisdictions allow such actions (Dorfman and Hall 1998). 
The phenomenon results from that insurer's bad faith---unfair insurance practices are governed by individual state laws rather than federal laws or statutes.

According to the American law, if a business entity is a named insured, then its owner, partner or executive likely are an "additional insured" under the insurance policy to which the insurer owes an implied contractual obligation of good faith and fair dealing. This means unsupported denial of any insurance claim, including claims under policies covering auto, disability, life, health and property -- such as homeowners or casualty claims, may subject the insurer to damages that go far beyond the amount that the company should have paid under the insurance policy in a civil action. Therefore, if an insurance company fails or refuses to honor its contractual obligations and pay a valid claim, the insured have the right to bring a civil action for damages against that insurance company. In addition to suing for a "breach of contract", through which courts order the insurers to pay the claims; the insured might be able to bring a "tort" claim seeking damages based upon the insurer's bad faith in handling of the claim. This means that besides what the insurer owes the insured under the policy (plus interest), if the denial can be shown to have been "unreasonable", the insured might also recover "consequential damages" (monies the insurer had to pay out-of-pocket because of the denial), and "extra-contractual damages" to compensate for mental and emotional distress. In such cases, courts have ordered claims payment, covering indirect damages and damages for mental and emotional distress, plus the recovery of pretrial interest, and legal fees.

Additionally, in some cases, for example, the cases of outrageously offensive behavior, such as: (1) elements of fraud (a deliberate attempt to deceive); or (2) a deliberate refusal to fulfill a contractual duty prompted by an honest mistake, punitive damages would be imposed on the insurer (Dorfman and Hall 1998). This is because, in these circumstances, usual legal remedies are insufficient to achieve society's goals, and thus, "punitive" or "exemplary damages" is designed to punish an insurer and deter the insurer and its employees from wrongfully denying similar claims in the future. Therefore, punitive damages are not as compensation for injuries suffered, but as a means of punishing defendants for offensive acts. In order to recover punitive damages, one must prove that the insurer has acted with "oppression, fraud, malice or despicable", which are specified in local state statutes. Where the plaintiff satisfies the statutory burden of proof in first or third-party insurance cases, courts may award punitive damages in accordance with the following three criteria in fixing the amount of punitive damage (Neal v. Farmer's Ins. Exchange Cal. 1978):

(1) The degree of reprehensibility of the insurer's act;

(2) The amount of actual harm as measured by the amount of compensatory damages; and

(3) The over-all wealth of the insurer for purposes of judging the deterrent effect to be achieved by a particular amount of punitive damages.

In essence, the legal system of bad faith lawsuit is designed to against an insurer's conduct that is in inconsistent with what a reasonable policyholder would have expected, hence, such behavior is not in good faith (Harrington and Niehaus 2003). Under the American insurance law, the economic reasons supporting bad faith lawsuits are based on such justification:

"Market incentives and normal judicial remedies for breach of contract may be insufficient to prevent some insurers from behaving opportunistically by refusing to pay claim costs or by offering to pay too little for claims." (Harrington and Niehaus 2003 ).

It should be noted that insurer's duty of "good faith and fair dealing" with insured under a policy, is implied by the law, instead by the contract. Therefore, the breach of this non-consensual duty constituted a tort separate, and distinct from any action in contract under the policy. This is primary reason why the cause of action for bad faith litigation is an insurer's tortuous action instead of breach of contract.

\subsection{The Requirements for Establishment of Bad Faith Lawsuit}

There are two requirements for the establishment of bad faith lawsuit. The first is procedural requirement, which requires an insurer's adequate investigation to insured's claim. The second is substantive requirement, which require insurer's denial or refuse should be sustained with reasonable grounds. Thus, if an insured desires to win bad faith litigation, he/she must prove that an insurer's refusal or denial to his/her claim has been in unreasonable grounds or inadequate investigation. In other word, a legitimate dispute or disagreement over coverage or benefits will likely not give rise to a bad faith lawsuit. For example, insurance claims are denied for many legitimate reasons, including fraud committed by an insured.

Turning first to the procedural requirement, what is adequate investigation? Timely and thorough investigation is required. The procedural requirement emphasizes that an insurer shall investigate carefully, by collecting both evidences that are in non-favorable for and in favor of the insured; particularly important, the insurer shall gather those evidences that are in helpful for the insured. Therefore, the essence of the procedural requirement is that, when dealing with insured's claim, an insurer must give as much consideration to the financial interest of the insured as the insurer gives to 
its own financial interest. This is why any refusal or denial to an insured's claim resulting from an insurer's negligent investigation may constitute bad faith lawsuit.

As far as substantive requirement is concerned, "reasonable grounds" for denying or refusing insured's claim, should satisfy following two conditions: (1), the refusal or denial should be sustained with sufficient evidences; otherwise, mere suspicion and speculation for new evidence may fall within bad faith; (2), sufficient evidences should at least include three kinds of evidences as follows: one is the evidences that prove whether or not the insurance accident or event has been actually happen; another is the evidences that prove whether or not the insured is entitled to obtain the indemnity or proceeds under the policy; and the third, is the evidences that prove the exact amounts of indemnity or proceeds that shall be paid under the insurance policy, if the insured has right to receive the indemnity or proceeds.

The case of Livingstone v. Auto Owners Insurance Co (1988) provides us a good illustration as to what are unreasonable grounds. In this case, the plaintiff was an insured, on May 1988, whose residence was destroyed by fire. The defendant, an American insurance company, as plaintiff's insurer, suspected arson by the insured, and thus, engaged in investigators to check the fire scene. On July, the report made by the investigators stated that it is believed that the fire was intentionally set, but failed to identify who was the arsonist. According to the report, the insurer delayed the payment of the claim. Consequently, on August, the insured brought a litigation to recover the profits of the policy. The judgment made by the Alabama Supreme Court was in favorable for the insured:

"Where evidence of arson by the insured was slight, mere suspicion and speculation the new evidence will present it at some future date is not reasonable grounds upon which to deny a claim."

When discussing what are reasonable grounds for refusing or denying insured's claim, a particular important issue is to correctly understand the relationship between an insured's right to recover the full value of his/her loss and an insurer's settlement against insured's claim for less than the full amount. One hand, the principle of utmost good faith empowers an insured the right to recover the full value of his/her loss; on the other hand, insurers often seek to settle claims for less than the full amount that an insured is entitled to recover. It is believed that no bad faith can be shown if the offer for settlement is a reasonable one. However, if an insurer, in order to save its money, offers a settlement that is completely out of line with insured's actual damage, or tries to take advantage of a difficult financial situation that the insured are in, may be found to be a conduct of bad faith. Intentional low-balling is simply a type of bad faith.

Particular attention should be paid that, under American insurance law, in addition unreasonable grounds as a general standard for determining an insurer's bad faith, there are separately certain specific criteria for determining bad faith under third or first-party insurance. This is because, under a third-party claim, the bases for the causes of action in bad faith and the available remedies are quite different from that under a first-party claim. In third-party claims, the insured is seeking defense and indemnification from liability to a third party, whereas in first-party claims, the insured is seeking indemnification from the insurer for a loss suffered by the insured personally (Dobbyn 2001).

\subsubsection{Specific Criteria for Determining Bad Faith in Third-Party Claim}

Under a third-party claim, according to, there are eight factors listed by American court for a comprehensive consideration concerning whether or not the insurer's refusal constitute a bad faith (Dobbyn 2001). They are:

(1) The strength of the injured claimant's case on the issues of liability and damages;

(2) Attempts by the insurer to induce the insured to contribute to a settlement;

(3) Failure of the insurer to properly investigate the circumstances so as to ascertain the evidence against the insured;

(4) The insurer's rejection of advice of its own attorney or agent;

(5) Failure of the insurer to inform the insured of a compromise offer;

(6) The amount of financial risk to which each party is exposed in the event of a refusal to settle;

(7) The fault of the insured in inducing the insurer's rejection of the compromise offer by misleading it as to the facts; and

(8) Any other factors tending to establish or negate 'bad faith' on the party of the insurer.

The eight factors was specified by California court in the seminal case of Brown v. Guarantee Insurance Company (Cal. App.1957), which give a concrete guidance in actual fact situation, for deciding what an insurer's "good faith and fair dealing" is or "what the practical definition of bad faith should not be" under a third-party claim. In this case, the insured had been sued in tort for $\$ 15,000$. The insurer under an automobile liability policy assumed the defense and rejected an offer of settlement at the policy limit of $\$ 5,000$ without even informing the insured of the offer. The insurer expressly took the position that it had no reason to settle the case unless could save some money on the settlement. It was held by the court that the insurer failed to consider the interests of the insured in refusing to settle an action by a third party, and therefore constitute bad faith. 


\subsubsection{Specific Criteria for Determining Bad Faith in First-Party Claim}

The principal examples of first-party insurance that have been the subjects of bad faith actions are insurances of life, health, fire, accident, disability, medical payments, hospitalization, theft, and uninsured motorist.

The leading precedent for a cause of action in bad faith in first-party claim is Gruenberg v. Aetna Ins. Co. (Cal. 1973). In this case, the California Supreme Court held that "the duty of good faith and fair dealing required not only that the insurer accept reasonable settlements in third-party insurance cases, but also that the insurer not unreasonably withhold payments due its insured under a policy of first-party insurance".

When deciding what kinds of conducts constitute bad faith under first-party insurance, in Chavers v. National Security Fire \& Casualty Ins. Co. (Ala.1981), the applicable criterions have been defined as the existence of "no lawful basis for the refusal coupled with actual knowledge of that fact" or "intentional failure to determine whether or not there was any lawful basis for such refusal."

According to National Security Fire \& Casualty Ins. Co. v. Bowen (Ala.1982), the following specific elements can be applied for further definition regarding "the lack of a lawful basis" or "the lack of reasonable grounds" for refusal to pay:

(1) An insurance contract between the parties and a breach thereof by the defendant;

(2) An intentional refusal to pay the insured's claim;

(3) The absence of any reasonably legitimate or arguable reason for that refusal(the absence of a debatable reason);

(4) The insurer's actual knowledge of the absence of any legitimate or arguable reason;

(5) If the intentional failure to determine the existence of a lawful basis is relied upon, the plaintiff must prove the insurer's intentional failure to determine whether there is a legitimate or arguable reason to refuse to pay the claim.

\subsection{Insurers' Delay to Insureds' Claim and Bad Faith Lawsuit}

When discussing bad faith lawsuit, it is necessary to mention an insurer's delay to an insured's claim. If an insurance company appears to be simply dragging its feet on the insured's claim, the delay do not usually constitute a bad faith conduct and the insured can send a written complaint to the insurer's adjuster. The better manner for dealing with this problem is to politely ask who the claim adjuster's supervisor is and send him/her a detailed and direct letter. If the delay does not appear to stop, and the delay is obviously beyond the reasonable time within which the insurer's answer to the claim should be responded, then, the insurer's delay may constitute a bad faith. This is because under this circumstance, the insurer's behavior constitutes an omission that harm the insured's right to obtain indemnity or benefit form the insurer. The insured may need to contact a lawyer, through whom, with lawyer's letter, politely and rationally, but directly and firmly, ask for a written response within a (reasonable) specified time. Such kind of warning or threatening to sue them for their delay is necessary for further launch of bad faith lawsuit. In such a circumstance, because of the insurer's delay in claims payment, the court will impose the insurer to a bad faith claim for punitive damages, which is likely many times of compensatory damages awarded.

\section{Chinese Insurance Law and Practices for Solving Insurers' Bad Faith}

The above statement and discussion on bad faith lawsuit in the U.S., is for solving the problem of insurers' bad faith in China. The problem in China is still serious. According to a report issued by the China Protection Association of Consumers' Rights and Interests (2005), in recent years, insurance consumers' main complaints against China's insurance industry, focus mainly on insurers' bad faith. For example, for the intention of refusing payment, some insurance companies one-sidedly and unfairly explain the stipulations of insurance clause and policy, or when investigating an insured's claim, simply collect the facts and evidences that are unfavorable for the insureds, whereas neglect favorable one. These conducts infringe not only policyholders' right for indemnity or benefit; also impede healthy development of Chinese insurance industry. In order to efficiently resolve the problem, Chinese government and insurance industry itself have implemented a number of measures, including legislative, judicial, administrative and industrial measures; but, better legal mechanism for against the bad faith is still needed to be studied.

\subsection{Traditional Legal Mechanisms for Solving Insurers' Bad Faith in China}

Unlike USA, statute in China is the sole legal source, which including laws, regulations and rules, and judicial explanation of Supreme People's Court (SPC). The Chinese Insurance Law is a basic statute in the field of insurance law. To solve the problem of insurers' bad faith, the Chinese Insurance Law adopts two legal approaches: the first is remedy for breach of contractual obligation, a method of private law; the second is punishment, the method of public law, covering criminal sanction and administrative penalty. For the intent of the legislation, these two methods are designed to be applied together. 


\subsubsection{Remedy for Breach of Contractual Obligation}

In the respect of private law, articles 23, 24, 25 and 26 of the Chinese Insurance Law, as general provisions, deal with the affairs of claim and payment under an insurance policy. The purpose of these obligatory provisions is to ensure an insurance company dealing with insureds' claim in good faith. Among these provisions, the most important one is paragraph (1) and (2) of article 24, which provides:

"The insurer shall, after receipt of a claim for indemnity or for payment of the amount insured from the insured or the beneficiary, determine the matter without delay, and inform the insured or the beneficiary of the result of the determination. Where responsibility lies with the insurer, the insurer shall fulfill its obligation for such indemnity or payment within 10 days after agreement is reached with the insured or the beneficiary on the amount of such indemnity or payment. If there are stipulations in the insurance contract on the sum insured and on the period within which indemnification or payment should be made, then the insurer shall fulfill its obligation accordingly.

If the insurer fails to fulfill its obligations as prescribed in the preceding paragraph in a timely manner then, in addition to payment of the amount insured, the insurer shall compensate the insured or the beneficiary for any damage incurred thereby."

According to these provisions, an insurer has an obligation to act in good faith, which requiring an insurer to make a proper investigation to an insured's claim concerning both the extent of loss and whether the event is covered under an insurance policy. Thus, the insurer is obligated to adjust the insured's claim, even if the insured do not know the extent of the claim or terms of coverage which might apply, assuming the insured have not gone by the time specified in the policy to submit a claim.

Under paragraph (1) of article 24, there is no doubt that an insured may seek contractual remedies if an insurance company fails or refuses to pay the amount that should be paid pursuant to the terms and conditions of an insurance policy.

In practice, the key issue is, under paragraph (2) of article 24 , what is exact meaning of "any damage"? In other words, "any damage" in this provision whether or not includes "extra-contractual damages" for mental damage and emotional distress plus legal fees, and punitive damages for deterring insurer's wrongful doing if an insurer's refusal or deny to insured's claim is outrageously offensive behavior? If covering these, it has not doubt that this provision provides a legal basis of tort litigation, exactly like bad faith lawsuit under the American insurance law.

Regretfully, According to existing judicial practice, "any damage" in this provision fails to cover "extra-contractual damages and "punitive damages" mentioned above. This is because, under PRC legal system, article 24 (2) of Chinese Insurance Law should be applied by combining with the corresponding provisions of the Contract Law of PRC. It is general held that, if an insurer fails to act in good faith in responding an insured's claim in accordance with paragraph (1) of article 24, the insured is only entitled to bring a lawsuit for enforcing the policy, and to seek all available legal remedies for the breach, including court-compelled performance and damages. If successful, the insured will be able to recover a payment by the insurer. The payment covers: (1) the amount that is equal to the insurer should have paid under the terms of the policy, and (2) the damages, including the expenses that were incurred because of the breach and count's administrative expenses for the lawsuit, but, dose not includes extra-contractual damages for mental and emotional distress, punitive damages, and other damages, such as attorney's fee.

The mechanism of contract law and the scope of compensation for handling insurer's bad faith demonstrate that there is not legal system of bad faith lawsuit in the Chinese Insurance Law. Therefore, it can be further concluded that the legal basis supporting article 24(2) is the theory of breach of contract instead of tort. This is why, as we said forgoing, there is not legal mechanism of bad faith lawsuit in China.

\subsubsection{Criminal Sanction and Administrative Punishments under the Law}

In the side of punishments based on public law, both criminal law and administrative law are applied against insurers' bad faith. Article 139 of the Chinese Insurance Law provides:

"Where the insurance company refuses to fulfill its obligation agreed to in the insurance contract to pay indemnity or insurance benefits, if the violation constitutes a crime, the insurance company should be investigated for criminal responsibility in accordance with law; if the violation is not serious enough to constitute a crime, the insurance supervision and control authority shall impose on the insurance company a fine of not less than 50,000 yuan but not more than 300,000 yuan; the staff member who violates the law shall be fined not less than 20,000 yuan but not more than 100,000; and if the circumstances are serious, restrictions shall be imposed on the business scope of the insurance company or the company shall be instructed to cease accepting new insurance business."

Reviewing practical effectiveness of the article after the Chinese insurance law has been carried out more than ten years, it could be concluded that its legislative purpose has failed to be achieved. This has been proved by the annual report (2004-5) of China's Protection Association of Consumer's Rights and Interests. Moreover, there are following obvious 
shortcomings in applying the punishment based on public law to solve the problem of insurer's bad faith, which, in nature, should be regulated and adjusted by the remedy of private law, including both remedy under contract law and damages under tort law (Huang QH 2007a): (1) the punishment of public law can not provides fully remedies for insured, the reason has been entirely stated as above; (2) the punishment of public law is more expensive than remedy of private law, furthermore, the cost for deciding and executing the punishment of public law is paid from public finance rather than the insurers acting in bad faith, which observably increase the payment of public finance; (3) the punishment of public law can not be carried effectively out for its legislation purpose in such a country where rule of law is not prevailed; (4) the punishment of public law may empower government and its staffs obtain more opportunities to intervene with economic activities and social life, which often results in the abuse of public power.

Reviewing these disadvantages from jurisprudence, insureds' right that is infringed by insurers' bad faith belongs to private right, therefore, it can be, more importantly, shall be governed by private law instead of public law. Consequently, it is obviously better to solve insurers' bad faith with fully compensation and civil fine than criminal or administrative punishments. This is because there are many advantages in the remedy of private law than the penalty of public law: first of all, remedy of private law can provide enough compensation for insureds, hence, can encourage people to struggle with bad faith; moreover, the cost of remedy of private law shall be borne by defendant rather than public finance, therefore, can save the payment of public finance; furthermore, the approach of remedy of private law can effectively restrict the applicable scope of government's public power; finally, the remedy of private law may cultivate individuals' legal beliefs and legal feeling because the remedy can provide effective protection to the individuals' legitimate right(Huang QH, 2007b).

In addition, observing article 139 of the Chinese Insurance Law from legislation technique, it is difficult to define the distinction between crime and non-crime in the case of insurers' bad faith. Hence, there is also trouble in practicability of the provision. This is another reason why the problem of insurers' bad faith in China can not be effectively solved for long time.

\subsection{New Practices for Preventing and Handling Insurers' Bad Faith in China}

In order to efficiently resolve the problem of insurers' bad faith, "Certain Opinions on Reform and Development of China's Insurance industry" (hereafter referred as "Certain Opinions") issued by China's State Council in 2006 requires that, the operation of Chinese insurance industry shall be in good faith and standard. For this purpose, "Certain Opinions" require establishing insurance credit system, pushing the construction of good faith culture, and creating an excellent environment for the development of Chinese insurance industry. Specific measures for fulfilling the goal include providing intensive education of good faith for insurance staffs, strengthening the construction of self-disciplined organizations in insurance industry, and introducing effective mechanism of punishment and warning against the bad faith.

Under the direction of "the Certain Opinions", the China's law section is discussing the amendment and betterment of the Chinese Insurance Law. In addition, China's courts and governmental agencies, such as the insurance supervision and control authority (ISCA), as well as insurance companies themselves are respectively taking the measures of justice, administration and self-discipline.

\subsubsection{Amendment of the Chinese Insurance Law}

In the respect of amendment of the Chinese Insurance Law, as far as the legal issues of insurer's post-contractual obligations are concerned, particularly, the insurer's duty of good faith in the performance of insurance contract, it has been realized by the Chinese Insurance law sector that the following problems of legislation should be solved:

(1) It is necessary to define that insurers' post-contractual obligations concerning good faith, including 1) insurer's illustration obligation on contractual terms and conditions involved in the stage of performing policy; 2) insurers' inform duty on requiring an insured to supplement evidences and relevant materials when dealing with the insured's claim; 3) insurers' duty of timely and properly investigating an insured's claim; 4) insurers' inform duty on dissolution of insurers' contractual liability because of an insured's violation to warranties clause on the truth of information provided; 5) insurers' inform duty when an insured violating good faith duty (for example, fails to pay premium pursuant to the stipulation of a policy); 6) the disposal of insurers' negligent liability of concluding contract discovered; and 7) insurers' inform obligation on modification and renewal of a policy after the insurance policy is concluded.

(2) Relation to an insured's obligation of "timely inform" after the happen of an insurance accident, it is necessary to describe that, 1) after an applicant, insured or beneficiary knows the happen of a covered accident, the information concerning the accident to the insurer within reasonable time, should belong to the governing scope of the insured's obligation of "timely inform" provided by Article 22(1) of the Chinese Insurance Law (note 1); 2), an applicant, insured or beneficiary's failure to timely inform the insured accident do not influence insurer's insurance liability, except for otherwise stipulation in the contract; and hence, 3) an insurer's defense that it should not bear insurance liability 
because of a plaintiff's failure to timely notify the insurance accident in question, should not be sustained by people's court.

(3) By reference to the UK's case law, the Chinese Insurance Law should add a provision that both parties' post-contractual obligation on good faith will/shall be ended after court accepts the case filed. After that, the relationship between parties to an insurance policy is regulated by civil procedure law.

\subsubsection{Judicial and Administrative Measures}

In the side of judicial measure, The SPC is drafting the judicial explanation concerning how the dispute of the performance of insurance contracts should be judged, and meanwhile, local people's courts at all level have sentenced a number of cases concerning the complaints of insurers' bad faith in accordance with article 24 of the Chinese Insurance Law and the Chinese Contract Law.

The Commence and Industry Administration Agency, together with the Protection Commission of Consumers' Rights and Interests, have co-issued several reports commenting on insurers' good faith and fair dealing in resent years. The reports is playing active role in directing consumers' acceptance of insurance service.

\subsubsection{Self-disciplinal Measure of insurance industry}

In the side of self-discipline of insurance industry, on June, 2006, the China Pingan Insurance Share Limited Corporation ("Pingan") issued a report, whose title was "Good Faith, The Pathway for 'Pingan' To Be A Citizenship", and through publishing the report, "Pingan" made a promise to the world that she will regard good faith as a basis and without it, "Pingan" believes that, insurance enterprise can not develop and progress. Therefore, she will actively perform corporate social responsibility for the community, and willingly defense all kind of conducts of bad faith.

After reviewing all above existing opinions and practices for preventing and handling insurers' bad faith in China, two basic conclusions can be made: first, Chinese government, law section, consumers' society and insurance industry, as well as insurance companies themselves, have made great efforts to deter the bad faith. Second, unfortunately, it is discovered that there is not a tort law mechanism of bad faith lawsuit, like bad faith lawsuit in USA, to develop and promote insurance industry's good faith culture in China. Consequently, in the next subsection, the article will discuss the suggestion regarding the introduction of the American legal system into China from the perspective of comparative law.

\section{Analyses of Jurisprudence and Suggestion}

\subsection{Analyses of Jurisprudence}

The fundamental differences between the lawsuit of bad faith and the lawsuit for breach of insurance contract are as follows:

Firstly, the legal basis supporting bad faith litigation is the provision of law, whereas in the lawsuit for the breach of insurance policy, relevant legal basis is the stipulation of contract. Therefore, without the provision of law on bad faith lawsuit, there is not legal authority by which, an insured can commence bad faith litigation against an insurer.

Secondly, since bad faith lawsuit based on tort law, the purpose of such kind of litigation is to punish a tortuous conduct rather than a behavior of breaking contract. Consequently, very important remedies in bad faith lawsuit cover extra-contractual damages for metal damage and emotional distress and punitive damages, while in the lawsuit of breach of contract, punitive damages is rarely applied.

The essence of bad faith lawsuit in USA is that American law emphasizes using the remedy of private law, particularly, extra-contractual damages and punitive damages, (the latter is a kind of civil fine), to protect private rights, including individuals' property right and personal right. In contrast, Chinese law stresses applying public law means, such as administrative fine and other administrative penalties. The difference of legal mechanism is outstandingly displayed in the American Insurance Law and the Chinese Insurance Law in preventing and handling insurers' bad faith, which stems from their distinction in legal philosophy. It is believed that American law stresses citizens' self-autonomy while Chinese law values governmental power of administration.

As foregoing statement, in China, many disadvantages existing in using public law methods to "protect" private right and to deal with legal affairs that shall be governed by private law. The present situation is obviously represented in the Chinese Insurance Law. This embodies the characteristics of Chinese law in transition period, during which China's economic system is reformed from plan-oriented economy to market-oriented economy.

\subsection{Suggestion for Introduction of American Bad Faith Lawsuit into China}

It should be realized that, as a guideline for the reform and development of China's insurance industry, "certain opinions" provides an opportunity for the introduction of American bad faith lawsuit to China. The importance of the introduction is embodied not only in that it can improve the Chinese Insurance Law and promote insurers' good faith, but also in that it can offer a scientific legal mechanism for the progress of Chinese legal system. 
It should also be realized that there are a great number of specific measures of legal reform should be adopted if the legal system of bad faith lawsuit is introduced:

First of all, to amend the Chinese Insurance Law by adding a provision: "where an insurer improperly treats an insured or beneficiary's claim or deny the claim without justified reasons, the insured or the beneficiary may bring a bad faith lawsuit against the insurer."

Second, the legislation on extra-contractual damages and punitive damages should be absorbed systematically into Chinese law, including their applicable scope, applicable conditions, and decisive factors by which the amount of extra-contractual damages and punitive damages in different circumstances of bad faith lawsuits can be decided.

In the final, for introducing the legal system of bad faith lawsuit into China, and for effectively implementing the legal system, the improvement of Chinese torts law is also required, and through which, major concepts such as "gross negligence", "malice", and "fraud" and their legal requirements for their establishment in law can be identified. Otherwise, the legal systems of extra-contractual damages and punitive damages can not be operated well in China.

\section{Conclusion}

Bad faith lawsuit in America, as a cause of action and a legal thinking, provides an effective legal mechanism for China to prevent and handle insurers' bad faith. Through the introduction of the litigation mechanism, Chinese legal system will be reformed significantly.

"Certain Opinions" present a guideline or provide an opportunity for China's law society to introduce the legal mechanism of bad faith lawsuit in America into China.

After the legal system is introduced into China, an insured can claim his/her right to indemnity or benefit, from both of stipulation of insurance policy and provision of Chinese insurance law directly, can obtain fully compensation than of that under existing legal mechanism, if insurers fail to deal with the insured's claim in good faith and fair dealing. The introduction has great value in China's modernization constructions in legal system, market-oriented economy and democracy (note 2).

\section{References}

Chavers v. National Security Fire \& Casualty Ins. Co. (Ala.1981)

China's Protection Association of Consumer's Rights and Interests (2005), The Annual Report (2004-5).

China Pingan Insurance Share Limited Corporation (2006). “Corporate Social Responsibility in 'Peian"” (in Chinese), reported by Chinese Business on September 25, 2006

Dobbyn J. F. (2001). Insurance Law, West Group, pp. 126, 129, 299-300, 305,318.

Dorfman. M. S \& Hall. P (1998). Introduction to Risk Management and Insurance, Sixth Edition, Prentice Hall, p.312

Harrington. S. E. \& Niehaus. G. R. (2003). Risk Management and Insurance, Second Edition, Irwin Press, p. 197.

Huang Qinghua (2007a). “The Penalty upon Shanghai Xianhe Hospital's Fraud in Medical Service and 'Strong Government' Model" (in Chinese with English abstract), A paper selected for attendance of $17^{\text {th }}$ World Medical Law Conference (October 2008, Beijing.)

Huang Qinghua (2007b), "Reflection to the Relationship between public law and Private law in China" (in Chinese), a summary of the lecture delivered on 8 January 2007 for senior judicial personnel in Yifa City, Guangdong Province, in press.

Livingstone v. Auto Owners Insurance Co, 1991-92 CCH Fire Cases, $p 9817$

Neal v. Farmer's Ins. Exchange (Cal.1978)

National Security Fire \& Casualty Ins. Co. v. Bowen (Ala.1982)

Zho Zhoufu, et al (2006). "Amendment and Improvement of Chinese Insurance Law" (in Chinese), available: www. china law. com /insurance law/index.htm. (17 ${ }^{\text {th }}$ March 2007).

\section{Notes}

1. Article 22(1) provides:" the applicant, the insured or the beneficiary shall, in good time, notify the insurer the occurrence of an insured event soon after they knew it."

2. This article was written during May 2006---June 2007 when the author studied as a visiting scholar of legal English at the Department of Legal English, Guangdong University of Foreign Studies and served as a senior (international) lawyer at Shanghai HaihuaYongtai Law Firm. 